JURNAL ABDI INSANI UNIVERSITAS MATARAM

Volume 8, Nomor 2, Agustus 2021

Homepage : http://abdiinsani.unram.ac.id. e-ISSN : 2657-0629

\title{
PELATIHAN AKUNTANSI TERAPAN BERBASIS ANDROID PADA USAHA MIKRO, KECIL DAN MENENGAH (UMKM) ANGGOTA KAMAR DAGANG DAN INDUSTRI INDONESIA (KADIN) KOTA MALANG
}

\section{Android-Based Applied Accounting Training On Micro, Small And Medium Enterprises (MSMES) Members Of The Indonesian Chamber Of Commerce And Industry (Kadin) Malang City}

Kartika Dewi Sri Susilowati ${ }^{*}$ Nur Indah Riwajanti, Riezky Amalia, Muhammad Muwidha, Hari Purnomo

*Jurusan Akuntansi., Politeknik Negeri Malang, Indonesia

Jl. Soekarno Hatta No. 09, PO Box 09, Malang 65145 - Jawa Timur

Alamat korespondensi: kartika.dewi@polinema.ac.id

(Tanggal Submission: 5 Mei 2021, Tanggal Accepted : 19 Agustus 2021)

\begin{abstract}
Kata Kunci : Abstrak :
UMKM, Kelompok UMKM mengalami kesulitan dalam menyajikan laporan keuangan Lamikro, yang handal dan memadai yang sesuai dengan Standar Akuntansi Keuangan Laporan yang berlaku. Akibatnya mereka tidak mengetahui secara pasti berapa Akuntansi tingkat keuntungan atau kerugian dari usaha yang sedang mereka jalani. Usaha Kegiatan Pengabdian Kepada Masyarakat (PkM) bertujuan untuk Mikro, SAK meningkatkan keterampilan pelaku UMKM dalam pembuatan dan EMKM penyusunan laporan keuangan yang memenuhi Standar Akuntansi Keuangan (SAK) EMKM (Mikro, Kecil dan Entitas Menengah) dengan menggunakan software aplikasi akuntansi LAMIKRO berbasis android. Kegiatan ini diikuti oleh 17 UMKM yang tergabung sebagai anggota Kamar Dagang dan Industri Indonesia (KADIN) Cabang Malang. Metode pelatihan yang digunakan adalah ceramah, demonstrasi dan praktek. Hasil dari kegiatan ini menunjukkan peserta mendapatkan kemudahan dalam menyusun dan mencetak laporan keuangan. Adapun kendala atau kesulitan yang dihadapi peserta (UMKM) adalah kurangnya penguasaan peserta terhadap penggunaan software aplikasi akuntansi LAMIKRO karena waktu pelatihan yang terbatas sehingga akan sulit untuk menerapkan format akuntansi sederhana tersebut setelah acara pelatihan berakhir.
\end{abstract}

Panduan sitasi / Citation guidance (APPA $7^{\text {th }}$ edition) :

Susilowati, K. D. S., Riwajanti, R. I., Amalia, R., Muwidha, M., \& Purnomo, H. (2021). Pelatihan Akuntansi Terapan Berbasis Android Pada Usaha Mikro, Kecil Dan Menengah (UMKM) Anggota Kamar Dagang Dan Industri Indonesia (Kadin) Kota Malang. Abdi Insani, 8 (2), 150-157. http://doi.org/10.29303/abdiinsani.v8i2.395 


\section{PENDAHULUAN}

Usaha Kecil, Menengah dan Mikro (UMKM) merupakan mesin penting yang mendorong pertumbuhan ekonomi suatu negara. Ketika krisis ekonomi melanda Indonesia pada tahun 1998, hanya sektor usaha UMKM yang mampu bertahan dari keruntuhan ekonomi, sedangkan sektor yang lebih besar justru kolaps. Hal ini menunjukkan bahwa UMKM hadir sebagai solusi sistem perekonomian yang sehat dan dapat mendukung stabilitas sistem perekonomian yang ada. Diharapkan peran UMKM ini akan terus meningkat, sehingga peran UMKM dalam perekonomian nasional akan terus mengalami peningkatan. UMKM juga memegang peran penting dalam menggerakkan ekonomi nasional yang mengalami perlambatan. Namun demikian, dibalik kontribusi UMKM terhadap perekonomian nasional yang cukup baik, ternyata masih banyak permasalahan yang sangat mendasar dalam industri ini, diantaranya kapasitas pengelolaan UMKM yang masih lemah, kualitas sumber daya manusia (SDM) masih terbatas dan sulit untuk masuk ke lembaga keuangan khususnya perbankan (Adiningsih, 2001). Klaim ini mendukung penelitian sebelumnya oleh Urata (2000), yang menunjukkan bahwa salah satu masalah utama yang dihadapi oleh UMKM adalah masih belum banyaknya UMKM yang bankable, yang memperoleh pembiayaan dari bank, yang penyebabnya adalah kurangnya transparansi pengelolaan keuangan atau kurangnya kapasitas mereka dalam pengelolaan keuangan sehingga tidak mampu menyediakan laporan keuangan yang baik sebagai prasyarat pembiayaan dari bank.

Laporan Bank Dunia (2015) menyatakan bahwa lebih dari 50\% UMKM di seluruh dunia kekurangan modal yang dianggap sebagai kendala utama pertumbuhan mereka. Situasi ini bahkan lebih buruk di banyak negara berkembang karena persyaratan jaminan yang tinggi, kurangnya ketrampilan manajerial dan struktur kelembagaan yang tidak efektif, jaringan terbatas serta lingkungan bisnis yang tidak menguntungkan (Ayyagari et al., 2008). Permasalahan UMKM yang juga banyak dikemukakan di berbagai penelitian sebelumnya adalah akses permodalan dan akses pasar (Pham, 2017), rendahnya kualitas SDM, inovasi rendah dan ukuran usaha(Geleta \& Talegeta, 2019) dan ineffisiensi produksi(Taiwo A et al., 2012). Dari berbagai permasalahan tersebut, kemudahan akses permodalan ke lembaga keuangan atau bank dianggap menjadi kunci dalam menyelesaikan permasalahan UMKM. Akan tetapi kemudahan akses ke permodalan saja tidaklah cukup. Untuk memperoleh kredit dengan mudah, UMKM harus menyediakan informasi keuangan yang lengkap, antara lain neraca, laporan laba rugi, penjualan dan pembelian, hutang dagang, biaya, perubahan modal, arus kas dan lain-lain. Masalahnya, ribuan UMKM di Indonesia dinilai belum bisa mendapatkan layanan perbankan karena pelaku UMKM sendiri belum mampu menunjukkan laporan keuangannya dengan baik, bahkan, ada juga laporan keuangan dari UMKM yang tercampur dengan keuangan pribadi.

Pembukuan dan pencatatan keuangan yang baik adalah hal yang sangat penting dan harus mendapatkan perhatian pelaku UMKM, karena informasi keuangan ini memberikan informasi terkait dengan kinerja usaha mereka. Namun sayangnya, masih banyak pelaku UMKM yang tidak memperdulikan masalah pengelolaan keuangan beserta pencatatannya merupakan hal yang krusial bagi perkembangan usaha. Alasan yang disampaikan oleh UMKM biasanya terkait dengan ketidakmampuan mereka dan kerumitan dalam melakukan pencatatan keuangan yang benar menurut kaidah-kaidah akuntansi. Untuk memberikan kemudahan kepada UMKM dalam penyusunan laporan keuangan yang baik dan benar, saat ini sudah tersedia beberapa aplikasi software berbasis android yang dapat membantu UMKM dalam melakukan pencatatan keuangannya. Aplikasi ini menyediakan fasilitas bagi UMKM untuk mencatat transaksi keuangan dengan cara yang sederhana, yang dapat menyediakan laporan keuangan yang memenuhi Standar Akuntansi Keuangan EMKM (Entitas Mikro, Kecil dan Menengah). Selama ini UMKM umumnya mengandalkan pengelolaan secara manual, dimana 
masih sulit menyajikan pelaporan keuangan yang handal dan memadai. Untuk mendukung kemampuan UMKM tersebut maka PkM ini dilakukan dengan tujuan untuk memberikan pelatihan kepada UMKM anggota KADIN Kota Malang tentang bagaimana menyusun laporan keuangan menggunakan software aplikasi LAMIKRO (Laporan Akuntansi Usaha Mikro) berbasis android. Kegiatan ini diharapkan mampu memberikan motivasi dan ketrampilan pada para pelaku UMKM anggota KADIN Kota Malang sehingga memberi kemudahan kepada mereka untuk melakukan pencatatan keuangan dengan memanfaatkan software aplikasi akuntansi berbasis android LAMIKRO yang dibuat oleh Kementerian Koperasi dan Usaha Kecil dan Menengah.

\section{METODE KEGIATAN}

Kegiatan PkM ini diikuti oleh 17 UMKM anggota KADIN Kota Malang dengan latar belakang usaha dari garmen, kuliner, percetakan dan catering. Narasumber PkM terdiri dari para dosen Jurusan Akuntansi Politeknik Negeri Malang dan perwakilan dari KADIN Kota Malang. Adapun pelaksanaan kegiatan PkM ini dilakukan secara offline (tatap muka) dengan menggunakan metode ceramah, demonstrasi dan praktek, bertempat di Jalan Semeru No. 12, Malang dengan tetap memperhatikan protokol kesehatan. Kegiatan pelatihan ini dibagi menjadi 3 tahap.

\section{Tahap Diagnostik}

Pada tahap ini dilakukan pre-test terhadap UMKM untuk melihat seberapa jauh pemahaman mereka terhadap konsep dasar laporan keuangan. Kegiatan pre-test ini dilakukan menggunakan kuesioner

\section{Tahap Pelaksanaan Pelatihan}

Tahap berikutnya adalah pelaksanaan pelatihan singkat terkait dengan aplikasi laporan keuangan LAMIKRO yang berbasis android.

\section{Tahap Evaluasi}

Pada akhir sesi dilakukan evaluasi terhadap pelaksanaan pelatihan untuk mengetahui feedback dari peserta dengan menggunakan kuesioner.

\section{HASIL DAN PEMBAHASAN}

Bentuk dari kegiatan PkM ini adalah pelatihan penyusunan laporan keuangan berbasis android pada 17 UMKM yang menjadi binaan Kamar Dagang dan Industri Indonesia (KADIN) Kota Malang. Hasil analisis terhadap kuesioner yang dibagikan menunjukkan adanya beberapa permasalahan UMKM sebagai berikut:

1) Kurangnya pemahaman UMKM tentang pentingnya laporan keuangan dalam dunia usaha

2) UMKM belum memiliki laporan keuangan yang sistematis dan terstruktur yang memenuhi Standar Akuntansi Keuangan EMKM.

3) Keuangan usaha dengan keuangan pribadi tidak dipisahkan.

Kondisi tersebut menyebabkan laba yang diperoleh, perkembangan usaha serta pengeluaran untuk kepentingan usaha tidak dapat diketahui dengan pasti.

Oleh karena itu, untuk meningkatkan kemampuan UMKM dalam menyusun laporan keuangan yang dimaksud maka kegiatan Pengabdian Kepada Masyarakat (PkM) ini dilakukan dalam bentuk pelatihan pembuatan dan penyusunan laporan keuangan yang memenuhi Standar Akuntansi Keuangan (SAK) EMKM (Mikro, Kecil dan Entitas Menengah) dengan menggunakan software aplikasi LAMIKRO berbasis android. Pelatihan ini dilakukan dengan tujuan untuk memberikan solusi dalam mengatasi permasalahan minimnya pengetahuan UMKM terkait dengan laporan keuangan dengan pelatihan singkat menggunakan aplikasi software keuangan LAMIKRO. Lamikro adalah aplikasi akuntansi sederhana untuk usaha mikro yang bisa digunakan melalui smartphone dengan sistem 
operasi android. Dengan sistem ini, maka posisi keuangan dapat diketahui dan dipantau setiap saat dari handphone mereka. Fitur yang ditawarkan oleh LAMIKRO ini cukup komprehensif meliputi entri jurnal, daftar jurnal hingga penyusunan Laporan Laba Rugi serta Neraca

Software aplikasi akuntansi LAMIKRO ini dipilih karena pertama, aplikasi ini disusun dan dikembangkan oleh Kementerian Negara Koperasi Usaha Kecil Menengah Republik Indonesia dengan mengacu pada Standar Akuntansi Keuangan (SAK) EMKM. Kedua, pelatihan singkat bagaimana menyusun laporan keuangan sederhana menggunakan aplikasi akuntansi LAMIKRO dapat diikuti dengan mudah karena dapat diakses menggunakan handphone yang mereka miliki sehingga mudah dipahami dan dapat dipraktekkan secara langsung kepada peserta. Ketiga, pelatihan dilakukan dengan metode ceramah dan demonstrasi serta praktek penggunaannya dengan cara menjelaskan dan memberi contoh tahapan-tahapan yang dilakukan dalam penyusunan laporan akuntansi sederhana, sehingga peserta dapat bertanya secara langsung kepada pemateri. Pada sesi ini juga diajarkan bagaimana meng-install aplikasi kedalam handphone peserta, bagaimana cara registrasi dan cara mengoperasikannya.

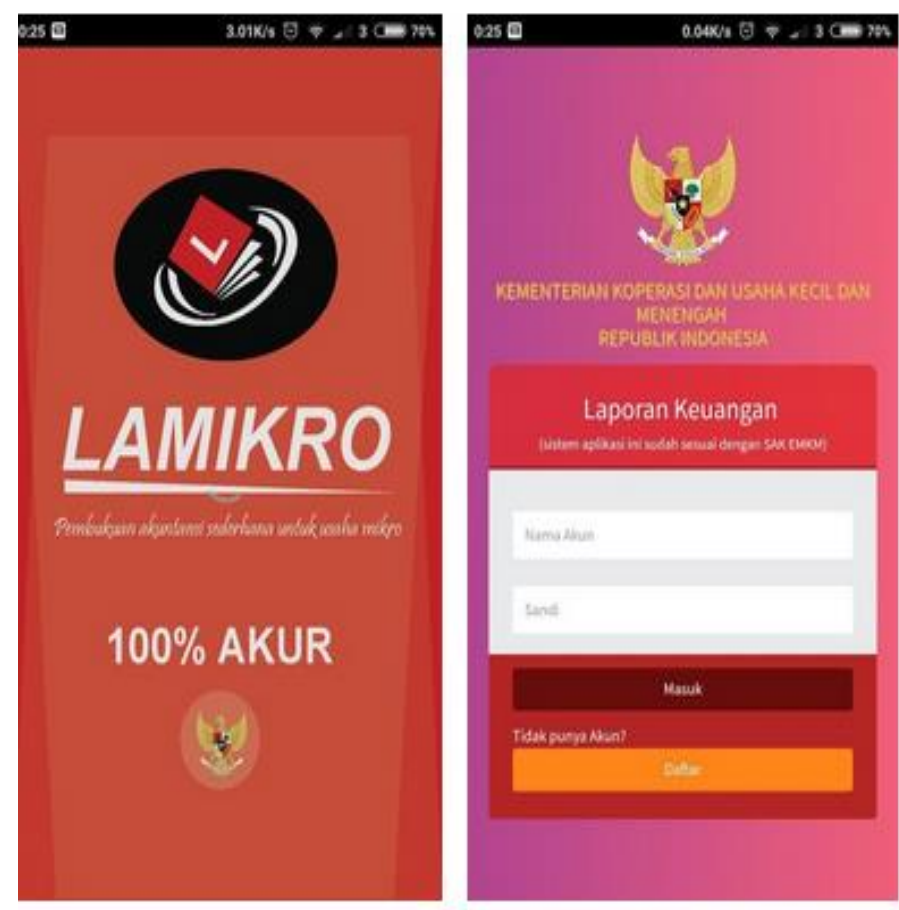

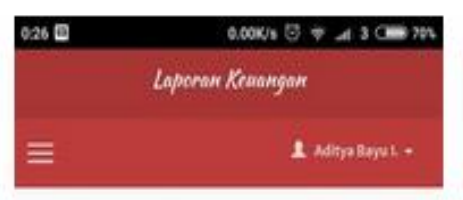
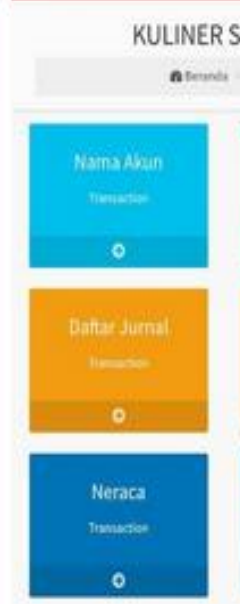

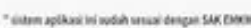

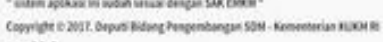
nemisio

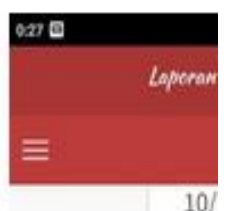

$10 /$

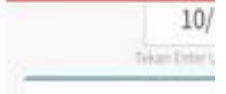

Aktiva

Aktiva Lancat

thes Mama Alam

1050 nas

1020 BUNK

1030 putwo ustha

1005 ntestowavian

Aktiva Tetap

Alas Hamation

1900 neuatisy

195 measusurest poretay

19 se sevcunas

las surouserem sevoukas

Gambar 1. Aplikasi LAMIKRO dari Kemenkop UMKM 


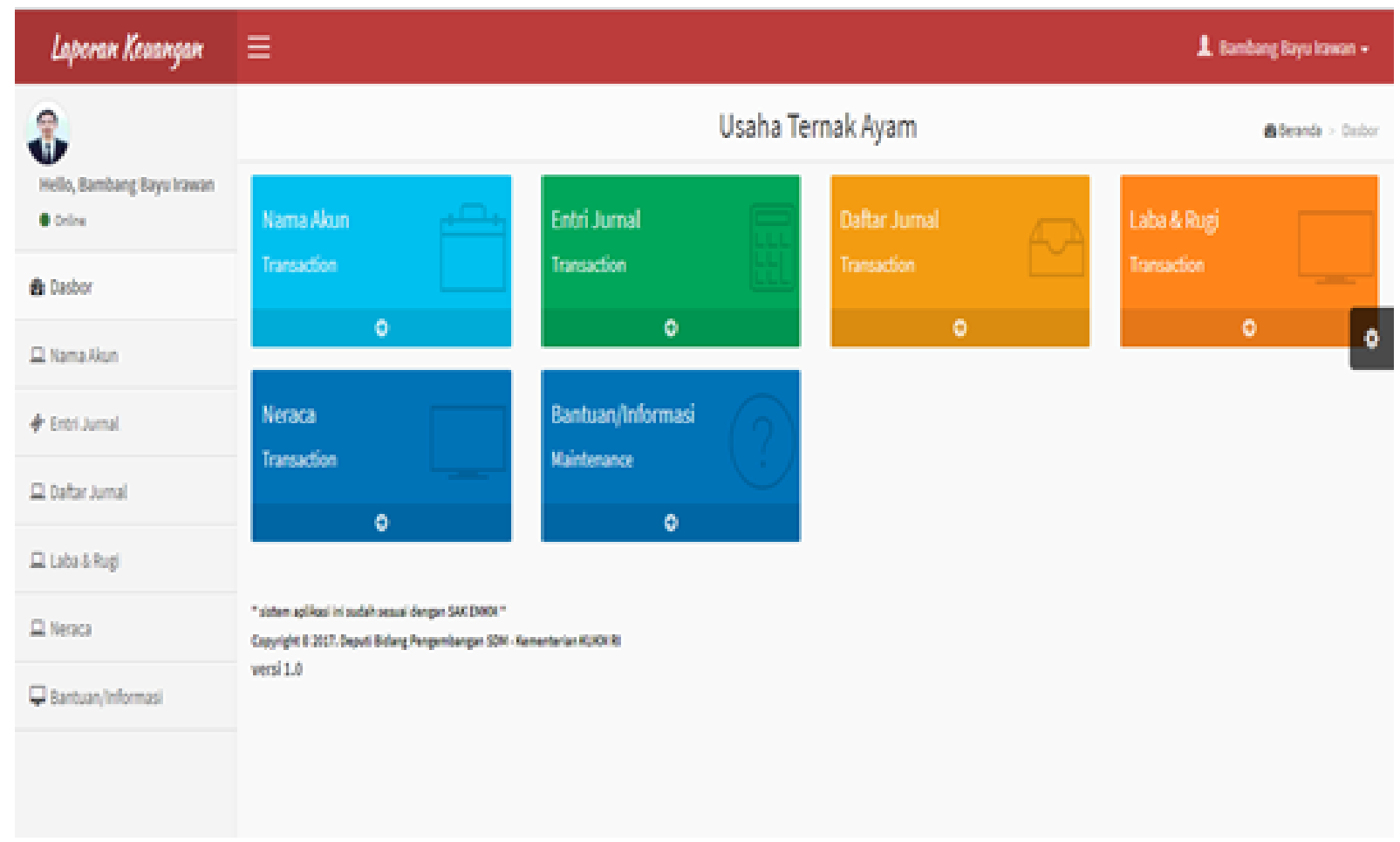

Gambar 2: Tampilan Utama LAMIKRO

\section{Tahap Diagnostik}

Pada tahap ini dilakukan pre-test terhadap UMKM untuk melihat seberapa jauh pemahaman mereka terhadap konsep dasar laporan keuangan. Kegiatan pre-test ini dilakukan menggunakan kuesioner dengan fokus utama untuk mengetahui pemahaman peserta terkait perbedaan aset dengan modal, proses akuntansi, perhitungan laba usaha, dan hal-hal lain terkait dengan akun-akun dalam laporan keuangan. Dari hasil pre-test diperoleh gambaran bahwa pemahaman peserta terkait dengan hal-hal tersebut diatas masih sangat kurang. Penyebab kurangnya pemahaman peserta terkait dengan proses akuntansi dan lain-lain adalah karena sebagian besar peserta (65\%) memiliki latar belakang pendidikan di bidang non akuntansi.

\section{Tahap Pelaksanaan Pelatihan}

Pada tahap ini, sebelum melakukan praktek penyusunan laporan keuangan dengan Lamikro, peserta diberi pelatihan singkat terkait materi akuntansi meliputi pengenalan konsep akuntansi termasuk pengenalan terhadap akun-akun yang digunakan dalam penyusunan laporan keuangan, peranan akuntansi dalam dunia usaha dan lain-lain. Setelah itu, secara bertahap peserta diberi pelatihan terkait dengan aplikasi Lamikro dan bagaimana cara menggunakannya. Pada sesi ini peserta diberi penjelasan terkait:

a) cara mendownload software aplikasi akuntansi LAMIKRO di Play-Store

b) cara melakukan registrasi dan mengisi data-data pemilik

c) cara melakukan login

d) akun-akun yang ada di aplikasi dan manfaatnya

e) contoh kasus transaksi keuangan dan menjelaskan cara memasukkan transaksi tersebut kedalam software aplikasi LAMIKRO.

f) cara menganalisis kinerja keuangan menggunakan rasio-rasio keuangan tertentu

g) cara mencetak laporan keuangan (Neraca dan laporan Laba Rugi) 


\section{Tahap Evaluasi}

Pada tahap ini, yang merupakan tahap terakhir dalam pelatihan penyusunan laporan keuangan menggunakan aplikasi LAMIKRO dilakukan evaluasi terhadap kemampuan para peserta pelatihan dalam menggunakan software aplikasi Akuntansi LAMIKRO. Pada tahap ini peserta diminta untuk memasukkan transaksi keuangan yang terjadi di usaha/ bisnis mereka masing-masing. Kegiatan ini dilakukan untuk mengetahui effektivitas pelaksanaan pelatihan dan daya serap peserta terhadap materi yang disampaikan selama pelatihan berlangsung. Setelah peserta melakukan registrasi, tim mulai menjelaskan tentang fitur-fitur yang disediakan oleh aplikasi LAMIKRO kepada peserta.

Pada sesi ini peserta juga diberi latihan praktek penyusunan laporan keuangan sederhana. Adapun materi yang diberikan meliputi penyusunan aset lancar (kas, persediaan barang dagangan, piutang dan perlengkapan), buku aset tetap (peralatan, bangunan dan mesin), hutang, modal dan penyusunan laporan keuangan (laporan laba-rugi dan laporan posisi keuangan) serta bagaimana mencetaknya. Selama kegiatan berlangsung, tim melakukan pendampingan kepada peserta agar mereka memiliki pemahaman dan penjelasan yang sama terkait materi yang disampaikan, dimana hal ini juga memberi peluang bagi UMKM untuk menanyakan secara langsung kepada tim apabila terdapat hal-hal yang belum jelas.

Evaluasi dilakukan pada sesi terakhir pelatihan dengan tujuan untuk melihat bagaimana tingkat pemahaman UMKM terhadap arti penting akuntansi dalam dunia usaha dan tingkat ketrampilan UMKM dalam mengoperasikan software aplikasi akuntansi sederhana berbasis android LAMIKRO setelah semua tahapan pelatihan dilaksanakan. Evaluasi juga dimaksudkan untuk perbaikan dalam pelaksanaan pelatihan di masa mendatang dan juga perbaikan dalam menerapkan format akuntansi sederhana pada UMKM. Selain itu, evaluasi juga dilakukan untuk mengetahui permasalahan atau kesulitan-kesulitan yang masih dialami UMKM dalam mengaplikasikan software akuntansi sederhana LAMIKRO, sehingga tim dapat memberikan solusi praktis untuk membantu UMKM dalam menyusun laporan keuangan sederhana atau hal-hal lainnya yang berkaitan dengan pengelolaan keuangan usaha. Tim memberi kesempatan bagi UMKM untuk berkonsultasi secara langsung dengan tim PkM terkait dengan usahanya dengan waktu dan frekuensi yang tidak dibatasi, menyesuaikan kesiapan dan kesediaan waktu masing-masing pihak.

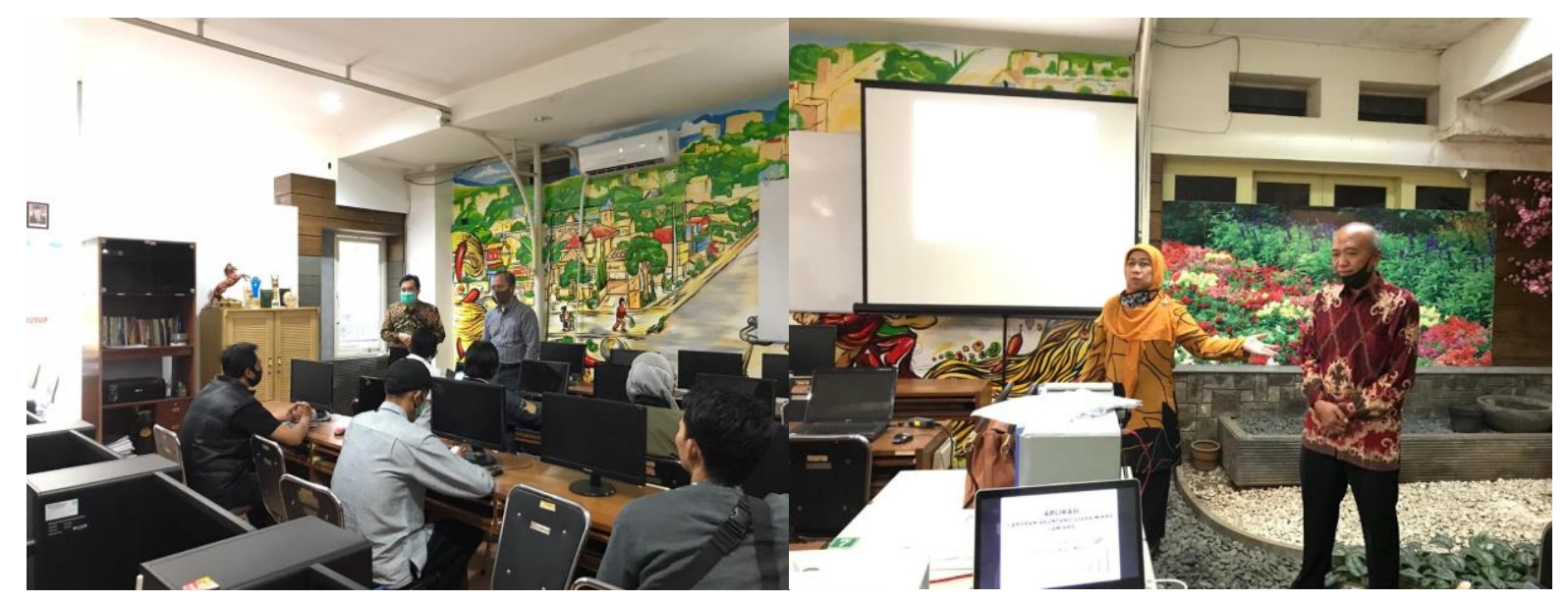

Gambar 3: Penyampaian materi pelatihan oleh tim 


\section{KESIMPULAN DAN SARAN}

\section{Kesimpulan}

Dari hasil evaluasi pasca pelatihan dapat diketahui bahwa kendala atau kesulitan yang dihadapi peserta (UMKM) adalah kurangnya penguasaan peserta terkait penggunaan aplikasi LAMIKRO karena waktu pelatihan yang terbatas. Setelah kegiatan pelatihan selesai, akan sulit untuk menerapkan format akuntansi sederhana dalam operasional usahanya sehari-hari karena takut salah. Kendala lainnya adalah penafsiran makna akun-akun dalam laporan keuangan belum dipahami dengan baik, karena sebagian peserta memiliki latar belakang pendidikan selain akuntansi. Kendala lain adalah menjelaskan makna yang terkandung dalam laporan keuangan, seperti pemahaman terkait mengapa aset tetap selain tanah harus disusutkan dalam nilai ekonomi, dan mengapa diubah menjadi beban penyusutan pada akhir periode.

\section{Saran}

Pengembangan usaha kecil, menengah dan mikro pada hakekatnya merupakan tanggung jawab bersama antara pemerintah dan masyarakat. Dalam mengkaji masalah-masalah yang dihadapi UMKM, saran yang dapat diberikan diantaranya adalah sebagai berikut:

1. Melindungi jenis usaha tertentu melalui undang-undang atau peraturan, terutama jenis usaha tradisional yang termasuk dalam kelompok ekonomi lemah.

2. Perlu dikembangkan budaya kemitraan antara UMKM, atau antara UMKM dengan pengusaha besar nasional dan asing, untuk menghindari monopoli usaha, memperluas pangsa pasar dan mengelola usaha lebih efektif . Dengan demikian, UMKM akan memiliki kekuatan untuk bersaing secara fair dengan pelaku usaha lain di dalam dan luar negeri.

3. Pihak-pihak yang selama ini memberikan pendampingan kepada UMKM, baik dari pihak pemerintah maupun non pemerintah perlu terjun ke lapangan untuk mengetahui secara langsung apa kebutuhan UMKM saat ini (utamanya pada masa pandemi ini) serta membuat pelatihan dan pendampingan yang sesuai dengan kebutuhan UMKM dari aspek kewiraswastaan, manajemen, administrasi dan pengetahuan serta keterampilannya dalam pengembangan usaha.

\section{UCAPAN TERIMA KASIH}

Tim PkM mengucapkan terima kasih kepada khususnya Politeknik Negeri Malang yang sudah memberi dukungan finansial bagi terlaksananya kegiatan pengabdian ini. Ucapan terima kasih juga kami sampaikan kepada semua pihak yang sudah membantu memfasilitasi pelaksanaan kegiatan PkM ini, baik penyediaan tempat maupun narasumber sehingga memberikan kemudahan bagi tim untuk melaksanakan kegiatan pengabdian ini. Ucapan terima kasih juga tim sampaikan kepada Ketua Kamar Dagang dan Industri Indonesia (KADIN) Cabang Kota Malang, bapak Heru Pamungkas, SH., MAP. yang sudah memperkenankan anggotanya untuk berpartisipasi sebagai peserta pelatihan dalam kegiatan PkM ini.

\section{DAFTAR PUSTAKA}

Adiningsih, S. (2001). Regulasi dalam Revitalisasi Usaha Kecil dan Menengah di Indonesia. Majalah IImiah Unikom Online, 7. https://docplayer.info/87289-Regulasi-dalam-revitalisasi-usaha-kecildan-menengah-dl-indonesia

Ayyagari, M., Kunt, A. D., \& Macsimivic, V. (2008). How Important are Financing Contraints? The role of finance in the business environment. World Bank Economic Review, 22(3), 483-516. https://elibrary.worldbank.org/doi/abs/10.1093/wber/lhn018 
Geleta, N., \& Talegeta, S. (2019). Determinants of Micro and Small Enterprises Growth in Selected Towns of West Shoa Zone, Oromia Regional State, Ethiopia. International Journal of Small and Medium Enterprises, 2(2). https://www.cribfb.com/journal/index.php/ijsmes/article/view/413 $\% 0 \mathrm{~A}$

Pham, H. D. (2017). Determinants of New Small and Medium Enterprises (SMEs) Access to Bank Credit: Case Study in the Phu Tho Province, Vietnam. International Journal of Business and Management, 12(7). https://www.ccsenet.org/journal/index.php/ijbm/article/view/67449

Taiwo A, M., Ayodeji M, A., \& Yusuf A, B. (2012). Impact of Small and Medium Enterprises on Economic Growth and Development. American Journal of Business and Management, 1(1), 1822.https://www.academia.edu/40044325/Impact_of_Small_and_Medium_Enterprises_on_Eco nomic 